\title{
Volatile Fatty Acid and Riboflavin in Cecal Contents of Rabbit under in vitro Incubation with Crude Fiber or Nitrogen Compound Addition
}

\author{
Tsutomu Yoshida, Keiko Nakatani and Makoto Kandatsu* \\ Tachikawa College of Tokyo, Azumacho, Akishima-shi 196 \\ * Azabu Veterinary College, Fuchinobe, Sagamihara-shi 229
}

(Received July 31, 1975)

\begin{abstract}
Cecal contents of the rabbit were sampled, diluted with the same weight of distilled water, supplemented with either crude fiber material or the nitrogen compounds (casein, egg albumin or glycine) and incubated anaerobically for 3 hours at $39^{\circ} \mathrm{C}$. Changes of $\mathrm{pH}$, true protein, crude fiber, volatile fatty acids (VFA), and dialysable and undialysable riboflavin were studied. VFA was fractionated to acetic, propionic, $n$-butyric and $n$-valeric acids. The results obtained are as follows. 1. Marked changes in the cecal contents after incubation with addition of crude fiber material were: i) decreased decomposition of true protein, ii) increased decomposition of crude fiber, iii) decreased VFA production, especially of acetic acid, iv) increased ribofiavin content, especially of the undialysable type. 2. Changes in the cecal contents after incubation with selected nitrogen compounds were compared with the control incubation without the compounds. A remarkable decrease in $\mathrm{pH}$ and increased decomposion of true protein were found when casein was added. However, neither addition of egg albumin nor glycine gave any definite effect, on the decomposion of true protein and crude fiber. Total VFA content was often increased by the addition of nitrogen compounds, especially by egg albumin which was also effective in decreasing molar percentage of acetic acid. The riboflavin content was not influenced by the casein, but increased by egg albumin and by glycine which stimulated production of dialysable riboflavin.
\end{abstract}

The provious report ${ }^{11}$, in which changes of the rabbit's cecal contents with time were studied, showed that the contents of crude fiber and the nitrogen varied inversely. The experiment reported here was designed to study changes of the cecal metabolic products by adding crude fiber or the nitrogen compounds to the cecal contents in vitro.

In the preceding paper ${ }^{21}$, in vitro anaerobic incubation technique of the cecal contents was investigated, in which the cecal contents were suspended with distilled water of equal weight ( 2 fold diluted contents) and incubated under $\mathrm{CO}_{2}$ gas for 3 hours at $39^{\circ} \mathrm{C}$. After incubation, 2 fold diluted contents differed little from the non-diluted contents, except for volatile fatty acid (VFA). Crude fiber material used in the present paper contained a small quantity of crude ash since it was prepared by a method similar to the determination of crude fiber in the diet, that is, by hot $1.25 \% \mathrm{H}_{2} \mathrm{SO}_{4}$ and $1.25 \% \mathrm{NaOH}$ treatments. In the preceding report ${ }^{2)}$, it was shown that quantity of crude ash obtained from crude fiber material was little affected by the incubation with the cecal contents.

Each component of the cecal contents before incubation was similar to shown in the previous results" ${ }^{11}$, and differences of the components of the cecal contents before and after incubation

Studies on Cecum Digestion XII.

Jap. J. Zootech. Sci., 47, (2): 87-94. 


\section{Yoshida, Nakatani and Kandatsu}

were compared. Total VFA, in which acetic acid was $3 / 4$, was $380 \mu$ mole/g dry matter. Total riboflavin, in which undialysable riboflavin was $2 / 3$, was $170 \mu \mathrm{g} / \mathrm{g}$ dry matter. After incubation, $\mathrm{pH}$ and the contents of true protein and crude fiber decreased. Total VEA and total riboflavin, especially acetic acid and dialysable riboflavin, increased during incubation.

The present report offers data of changes in the contents of crude fiber, nitrogen compounds, VFAs and riboflavins after anaerobic incubation of 2 fold diluted contents of the cecum in the case of the addition of crude fiber material or the nitrogen compounds.

\section{Experimental}

Materials: Japanese white rabbits (body weight $2.5-3.5 \mathrm{~kg}$, males) were used for the experiment. The animals were fed the diets, which were the mixture of wheat bran, hay plus commercial formular feed for the dairy cow manufactured by Nippon Formula Feed Mfg. Co. (1:1:1), of $150 \mathrm{~g}$ per day at $10 \mathrm{~A}$. M. The composition of the diets are shown in Table 1 . The cecal contents were taken out at 2 P.M. from the rabbits prevented from the coprophagy.

In vitro incubation technique: In vitro anaerobic incubation at a constant temperature of $39^{\circ} \mathrm{C}$ for 3 hours was carried out by the apparatus shown in previous paper ${ }^{2}$. Anaerobic condition was achieved by a streaming of $\mathrm{CO}_{2}$. Crude fiber material or the nitrogen compounds were added to the media of 2 fold diluted contents of the cecum.

The amount of crude fiber material added was $4 \%$ of the weight of the fresh cecal contents. As the fresh cecal contents usually contained $4 \%$ crude fiber, almost the same weight of crude fiber material was added to the fresh cecal contents and incubated.

For the same reason, the nitrogen compounds were added to the amount of $5 \%$ of the fresh cecal contents.

Casein, egg albumin and glycine were used as the sources of the nitrogen compounds. Casein is used for the present experiment since it is routinely used for nutrional research. Since protein in the cecal contents contained water-soluble protein in large quantities ${ }^{8)}$ and water soluble non-protein nitrogen of the cecal contents contained amino nitrogen abundantly ${ }^{4}$, egg albumin as the representative water-soluble protein and glycine as the representative neutral amino acid ${ }^{51}$ were used. The nitrogen contents of casein, egg albumin and glycine prepared for the experiment were $12.83,11.62$ and $17.76 \%$, respectively.

Table 1. Chemical composition of experimental diets

\begin{tabular}{lcc}
\hline & \multicolumn{2}{c}{ Diet } \\
\cline { 2 - 3 } & \multicolumn{2}{c}{ B } \\
\cline { 2 - 3 } Moisture & \multicolumn{2}{c}{$\%$ of air dry diet } \\
& \multicolumn{2}{c}{11.59} \\
Crude protein & \multicolumn{2}{c}{$\%$ of dry matter } \\
True protein & 14.74 & 14.94 \\
True Protein/crude protein $(\%)$ & 11.99 & 12.56 \\
Crude fat & 81.3 & 84.0 \\
Nitrogen-free extract & 3.54 & 6.53 \\
Crude fiber & 54.63 & 45.86 \\
Crude ash & 20.02 & 24.57 \\
& 7.07 & 8.10 \\
\hline
\end{tabular}




\section{VFA and Riboflavin of Rabbit Cecum}

Analytical methods: The value of $\mathrm{pH}$ was measured by the glass electrode $\mathrm{pH}$ meter of Toa Dempa HM-5A type, and crude protein, true protein and crude fiber were estimated as previously described ${ }^{(1)}$. Total VFA was determined by steam distillation ${ }^{2,6}$ ) using a semi-micro Kjeldahl distillation apparatus, and individual VFA (acetic, propionic, $n$-butyric and $n$-valeric acid') was separated by Shimazu RC1A gas chromatograph. ${ }^{7}$ Riboflavin was determined by the method of FujrTA ${ }^{8)}$. The separation of dialysable and undialysable riboflavin by the method of Euler et al. ${ }^{9)}$ was applied. Total riboflavin was shown as the sum of both type of riboflavin.

\section{Results and Discussion}

Changes of several components by incubation of 2 fold diluted contents of the cecum was studied with :the addition of crude fiber material or the nitrogen compounds. The results obtained are shown in Tables 2 and 3 . In this experiment, $\mathrm{pH}$ and the contents of the analysed components before and after incubation of the cecal contents, which were not supplemented with crude fiber material or the nitrogen compounds, were generally similar to the previous report'2).

1. Effect of crude fiber material addition

$\mathrm{pH}$ : Decreasing $\mathrm{pH}$ was always observed after incubation, but $\mathrm{pH}$ change was little affected with the crude fiber material addition.

True protein: The content of true protein was decreased after incubation, and the significantly reduced decomposition of true protein was found after incubation with the additional crude fiber material. The decomposition rates were reduced from $17 \%$ to $4 \%$. It was shown that the decomposition of true protein including the microorganisms was depressed by the crude fiber material addition. In addition to decreasing $\mathrm{pH}$, the increased decomposition of crude fiber and increased synthesis of riboflavin were observed in many cases with the addition as mentioned below. This may suggest that an increase of the microorganisms occurred by the addition of crude fiber material.

Data presented in the previous paper ${ }^{11}$ have demonstrated that the content of crude fiber and true protein/crude protein were the highest at $12 \mathrm{P} . \mathrm{M}$., and this is consistent with present data that true protein/crude protein increased after incubation with the crude fiber material addition. From these facts, it is possible to suppose that at night some cecal microorganisms increase and are more active than in the daytime.

Crude fiber: The crude fiber content decreased after incubation, and the significantly high decomposition rate of crude fiber was obtained after incubation with the crude fiber material addition. The average decomposition rates were about $5 \%$ and about $14 \%$ in the cases without and with the crude fiber material addition, respectively.

It is a very interesting fact that the decomposition of crude fiber is rather promoted by an increase of the crude fiber content.

VFA: In every case, increased total VFA was obtained after incubation. Compared with the case without the crude fiber material addition, the increase of total VFA fermentation in the case with the addition was not always observed. This was not in agreement with the experiment of Cools and JEUNIAUX ${ }^{10}$ on incubation of colloidal cellulose with extracts of the rabbit's cecal contents.

Although the decomposition of crude fiber during incubation increased in the case with 


\section{Yoshida, NAKaTANi and KandatsU}

Table 2. Changes in cecal contents after 3 hours of incubation with and without crude fiber material addition (dry matter basis)

\begin{tabular}{|c|c|c|c|c|}
\hline \multirow[b]{2}{*}{ : } & \multirow{2}{*}{$\begin{array}{l}\text { No. of } \\
\text { sample }\end{array}$} & \multirow[t]{2}{*}{$\begin{array}{c}\text { Before } \\
\text { incubation }\end{array}$} & \multicolumn{2}{|c|}{$\begin{array}{c}\text { After } \\
\text { incubation }\end{array}$} \\
\hline & & & $\begin{array}{l}\text { without } \\
\text { addition }\end{array}$ & $\begin{array}{l}\text { With } \\
\text { addition }\end{array}$ \\
\hline $\mathrm{pH}$ & 5 & $6.6 \pm 0.5^{\mathrm{a})}$ & $\begin{array}{c}6.2 \pm 0.6 \\
\%\end{array}$ & $6.1 \pm 0.5^{* 11}$ \\
\hline True protein & 4 & $26.52 \pm 4.90$ & $22.21 \pm 5.60^{* 11}$ & $25.48 \pm 4.20^{* 1,2)}$ \\
\hline True protein/crude protein & 4 & $78.8 \pm 4.7$ & $68.0 \pm 5.6^{* 11}$ & $75.7 \pm 5.8$ \\
\hline Decomposition ratio of true protein & 4 & & $17.0 \pm 7.5$ & $3.9 \pm 1.8^{* 21}$ \\
\hline Crude fiber ${ }^{\mathbf{b})}$ & 6 & $15.61 \pm 3.52$ & $14.73 \pm 3.47$ & $30.27 \pm 8.07$ \\
\hline Decomposition ratio of crude fiber & 6 & & $4.8 \pm 5.7$ & $14.3 \pm 5.6^{* 32}$ \\
\hline Volatile fatty acid & & & $\mu \mathrm{mole} / \mathrm{g}$ & \\
\hline Total & 4 & $341 \pm 73$ & $552 \pm 133$ & $455 \pm 65$ \\
\hline Acetic & 4 & $233 \pm 71$ & $344 \pm 104$ & $247 \pm 40$ \\
\hline Propionic & 4 & $36 \pm 14$ & $75 \pm 51$ & $69 \pm 36$ \\
\hline n-Butyric & 4 & $69 \pm 9$ & $133 \pm 30^{* 11}$ & $130 \pm 36$ \\
\hline \multirow[t]{2}{*}{$n$-Valeric } & 4 & $3 \pm 7$ & 0 & $9 \pm 6$ \\
\hline & & & lar $\%$ of 4 VFAs & $\because \cdots$ \\
\hline Acetic & 4 & $67.7 \pm 2.8$ & $61.9 \pm 2.2$ & $54.4 \pm 3.9 * 1,2)$ \\
\hline Propionic & 4 & $10.5 \pm 3.6$ & $12.5 \pm 6.3$ & $14.9 \pm 6.8$ \\
\hline$n$-Butyric & 4 & $20.9 \pm 4.1$ & $25.6 \pm 9.8$ & $28.8 \pm 7.7^{* 11}$ \\
\hline$n$-Valeric & 4 & $0.9 \pm 1.8$ & 0 & $1.9 \pm 1.4$ \\
\hline Riboflavin & & & $\mu \mathrm{g} / \mathrm{g}$ & \\
\hline Total & 4 & $188 \pm 89$ & $224 \pm 85$ & $294 \pm 162$ \\
\hline Dialysable & 4 & $69 \pm 42$ & $97 \pm 50 * 1)$ & $151 \pm 123$ \\
\hline Undialysable & 4 & $119 \pm 47$ & $\begin{array}{c}127 \pm 35 \\
\% \text { in total }\end{array}$ & $143 \pm 39 * 21$ \\
\hline Dialysable & 4 & $35.5 \pm 4.1$ & $41.9 \pm 4.8 * 11$ & $46.7 \pm 11.7$ \\
\hline Undialysable & 4 & $64.5 \pm 4.1$ & 58. $1 \pm 4.8^{* 11}$ & $53.3 \pm 11.7$ \\
\hline
\end{tabular}

a) Mean \pm S.D.

b) The statistical differences among the three groups were not analysed.

*1) Significant difference from "before incubation" at 5\% level

*2) Significant difference from "without addition" at $5 \%$ level

the crude fiber material addition as mentioned above, an increase of total VFA was not always observed by such a case. From the results of this investigation, it may be concluded that other components than crude fiber exist as the important origin of cecal VFA.

Of VFA content, acetic acid was the highest, next were $n$-butyric and propionic acids, and trace amounts of $n$-valeric acid were found. Lower production of total VFA and acetic acid was found after incubation with the crude fiber material addition. Since $\mathrm{HALL}^{11}$ observed that acetic and succinic acid were found in the highest concentration in the products formed from cellulose fermentation by the rabbit's cecal cocci, it is probable that succinic acid was greatly produced after fermentation in the present experiment.

The tendencies shown after incubation without the crude fiber material addition were observed more distinctly after incubation with the addition, such as the lower ratio of acetic acid, the higher ratio of propionic and $n$-butyric acid, and sometimes the occurrence of 
VFA and Riboflavin of Rabbit Cecum

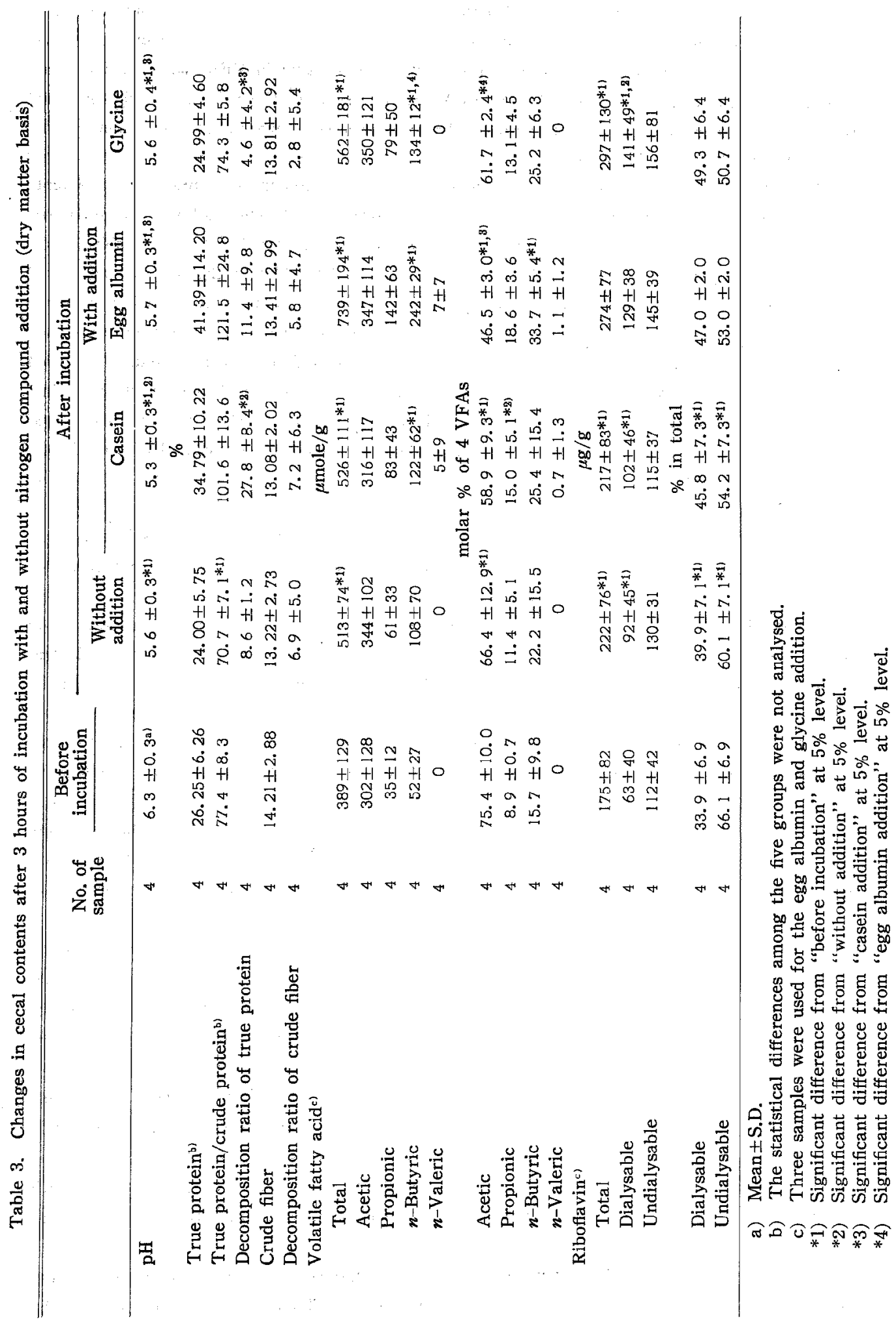




\section{Yoshida, Nakatani and Kandatse}

$n$-valeric acid. This is in agreement with the result obtained from the rumen contents of the goat fed diets containing high cellulose by Kumeno and Kandatsu'12). However, while the lower ratio of acetic acid and the higher ratio of propionic acid in VFA were shown after incubation of the contents, increased total VFA was observed in their data. On the basis of these data, it seemed reasonable to assume that the digestive process in the cecum is not always identical to that in the rumen.

Riboflavin: The riboflavin content increased after incubation and to a much larger extent with the crude fiber material addition. A number of works ${ }^{18,14,15)}$ has dealt with the effect of fiber on the intestinal synthesis of riboflavin in the other animals besides the rabbit, and such effect of crude fiber on riboflavin was also shown in the rabbit in the present report.

The increase of dialysable and undialysable riboflavin was shown after incubation with the crude fiber material addition, but the significant difference between incubation with and without the crude fiber material addition was obtained from undialysable riboflavin.

As it has been already indicated that water ${ }^{16)}$ and $V F A^{17)}$ are absorbed from the large intestine, it is suggested that the absorption of riboflavin may be worked through the large intestine. Besides, there is a possibility that unabsorbed riboflavin is ingested by the coprophagy and absorbed.

\section{Effect of nitrogen compound addition}

$\mathrm{pH}$ : The significant drop of cecal $\mathrm{pH}$ occurred after incubation with the casein addition, but not with the addition of the water-soluble nitrogen compounds (egg albumin and glycine), compared with the case without the addition.

Although previous work $\left.{ }^{8}\right)$ revealed that nitrogen in the cecal contents contained more water-soluble nitrogen than the other types of nitrogen, the reasonable conclusion to be drawn from available data is that cecal $\mathrm{pH}$ may be affected by an increase of the water-insoluble nitrogen compound in the cecal contents.

True protein: Decomposition of true protein during incubation was observed, except for the glycine addition. Compared with the case without the addition, true protein was significantly decomposed after incubation with the addition of casein, but a constant tendency was not observed in the case with the egg albumin addition. On the other hand, the least decomposition was observed after incubation with the addition of glycine. In view of the above fact, it is concluded that kinds of the nitrogen sources added affect greatly decomposition or synthesis of true protein.

Crude fiber: Except for one case, the crude fiber content after incubation decreased in all the cases with and without the nitrogen compound addition. Although a definite tendency was not found by the addition of protein (casein or egg albumin), a more depressed decomposition rate of crude fiber with the protein addition than that without the nitrogen compound addition was shown in some cases.

Thus, it was observed that the decomposition of true protein often occurred in the case on the protein addition to the cecal contents, but, on the contrary, the decomposition of crude fiber did not always occur and was sometimes depressed. This shows that the microorganisms in the cecum utilize protein and do not attack crude fiber in such a case. Compared with the other cases, decomposition of crude fiber by incubation with the glycine addition was very little.

VFA: Total VFA content was raised after incubation, and a large increase by the nitrogen compound addition was observed in many cases. There was a tendency that the 


\section{VFA and Riboflavin of Rabbit Cecum}

larger increase to total VFA was obtained by the addition of water-soluble protein (egg albumin). Present data are in agreement with the result of Minato et $a l \cdot{ }^{18,19}$ ) that more VFA was produced from the nitrogen compound (casein) than cellulose during artificial rumen fermentation.

The reasonable assumption to be drawn from present data is that water-soluble protein, which is found abundantly in the cecum of the rabbit, may be an important VFA source.

The higher content of each VFA was always obtained after incubation with and without the nitrogen compound addition. As for the molar percentage of each VFA, a decrease of acetic acid and an increase of propionic and butyric acid were found in many cases after incubation. Although a few exceptions were found, such a tendency was remarkable in the nitrogen compound addition. The effect of the nitrogen sources on the proportions of acetic and butyric acids agrees with the result of MAтsumoto et al. ${ }^{30}$ ) who observed the in vitro ruminal VFA production.

Compared with the addition of two other kinds of the nitrogen compounds, the significantly lower ratio of acetic acid in VFA was found in the case of the egg albumin addition, and the higher production and molar percentage of propionic and $n$-butyric acid were observed at the same time.

Riboflavin: The increased contents of total, dialysable and undialysable riboflavin and the higher ratio of dialysable riboflavin were always observed after incubation with and without the addition, and all the types of riboflavin increased after incubation with the addition of the water-soluble nitrogen compounds (egg albumin and glycine) compared with the case without the nitrogen compound addition. Moreover, dialysable riboflavin percentage after incubation with the nitrogen compound addition was higher than that without the addition.

It may be suggested from the results of the present investigation that the water-soluble nitrogen compounds have a definite effect on the synthesis of cecal riboflavin, especially dialysable type.

The authors are grateful to Dr. F. Kumeno, the Laboratory of Nippon Formula Feed Mfg. Co. Ltd., for his technical assistance on gas chromatography analysis.

\section{Reference}

1) Yoshida, T., and M. Kandatsu, Jap J Zootech Sci 39: 220-227. 1968.

2) Yoshida, T., K. Nakatani, and M. Kandatsu, Jap J Zootech Sci 46: 614-620. 1975.

3) Yoshida, T., and M. Kandatsu, Jap J Zootech Sci 30: 151-157. 1959.

4) Yoshida, T., and M. Kandatsu, Jap J Zootech Sci 31: 181-186. 1960.

5) Yoshida, T., and M. Kandatsu, Jap J Zootech Sci 35:64-69. 1964.

6) Kandatsu, M., and F. Kumeno, J Agr Chem Soc Jap 33: 255-258. 1959.

7) Kumeno, F., J Agr Chem Soc J p 36: 181-183. 1962.

8) Nagahara, T., and H. Iwao, Shyokuhin bunsekiho (Analytical method of foods), 1 st ed. 196-199. Shibata Shoten. Tokyo. 1958.

9) Euler, E. V., E. Adler, and A. Schlötzer, Z Physiol Chem 226: 87-94. 1934.

10) Cools, A., and C. Jeuniaux, Arch Internat Physiol Biochi 69: 1-8. 1961.

11) Hall, E.R., J Gen Microbiol 7: 350-357. 1952.

12) Kumeno, F., and M. Kandatsu, J Agr Chem Soc Jap 35: 360-367. 1961.

13) Yasuda, T., J Vitamin Jap 6: 7-13. 1954.

14) Nagase, H., J Vitamin Jap 6: 398-403. 1954.

15) Innami, S., and K. Kawashima, Jap J Nutr 18: 167-173. 1960. 
16) Yoshida, T., and M. Kandatsu, Jap J Zootech Sci 38: 358-363. 1967.

17) Hoover, W. H., and R. N. Heitmann, J Nutr 105: 245-252. 1975.

18) Minato, H., A. Endo, T. Koriyama, and T. Uemura, J Agr Chem Soc Jap 36: 101-106. 1962.

19) Minato, H., A. Endo, T. Kortyama, and T. Uemura, J Agr Chem Soc Jap 36: 106-110. 1962.

20) Matsumoto, T., K. Kobayashi, and T. KaWaguchi, Tohoku J Agr Res 14: 67-73. 1963.

\title{
粗䋐維や窒素化合物を添加後培養したウサギ盲腸内容物中の 揮発性脂肪酸とビタミン $\mathrm{B}_{2}$ について
}

\author{
吉田勉・中谷圭子・神立 誠* \\ 東京都立立川短期大学, 昭島市 196 \\ * 麻布獣医科大学, 相模原市 196
}

ウサギ盲腸内容物を探取し，等量の蒸溜水で希㭔し， 粗瀻維質や窒素化合物（カゼイン・卵アルブミン・グリ シン)を添加して, $39^{\circ} \mathrm{C} 3$ 時間の妌気培䬭を行い, 無添 加時と比較した. $\mathrm{pH}$, 純蛋白質, 粗瀻維, 揮発性脂肪酸 (VFA; 酢酸, プロピオン酸, $n$-酪酸, $n$-吉草酸に分別) およびビタミン $\mathrm{B}_{2}$ (透析型と非透析型に分別)の变化を 調べた，1）粗繊維質添加後の変化として，純蛋白質分 解の減少および粗繊維分解の増加が認められた。また， 全 VFA 生産やVFA 中に占める酷酸モル比の低下， および $\mathrm{B}_{\mathbf{2}}$ (とくに非透析型) の堌加が起こった．2）等
素化合物添加後の变化を見ると，カゼイン添加で $\mathrm{pH} の$ 低下や純蛋白質の分解が著しく，また純蛋白質分解法卵 フルブミン添加では一定せず，グリシン添加で減少し た. 粗繊維の分解に関しては一定の傾向が得られず，全 VFA 量注窒素化合物の添加でしばしば增加し，とくに 卵フルプミン添加で著しかった. 各 VFAのモル比で法 酷酸が低下し，これ卵フルプミン添加時に顕著であっ た。ビタミン $\mathrm{B}_{2}$ 量はカゼイン添加では影響がなく，卵 フルブミンやグリシン添加時には增加した。 